\title{
Jesuits and Communism: Introduction
}

\author{
Beth Ann Griech-Polelle \\ Pacific Lutheran University \\ griechba@plu.edu
}

During the horrendous fighting of the First World War, the Russian Empire was consumed by failure; failure to win victories against the German military, failure to feed its home population, and failure to maintain political stability. In the midst of wartime deprivation and devastation, the Bolshevik Party, led by an exiled Vladimir Lenin, campaigned on promises of "Peace, Bread, Land." For some of the people of the Russian Empire, the Bolshevik promise to withdraw from the military conflict raging around them was especially promising. For still others, the desire for a re-structuring of all Russian society along Marxist-Communist lines seemed to promise greater social equality for the large masses of the lower social classes. The moderate government of Alexander Kerensky, which refused to withdraw from the war, fell to the Bolshevik Party in October 1917.

As Lenin and his Bolshevik followers attempted to seize power, they unleashed a bloody and protracted Civil War within the empire. The "Reds" led by the Bolsheviks, sought to radically alter Russia to be in keeping with Marxist ideology. The "Whites" led by a mixture of conservatives, fought back, seeking to prevent the Bolshevik reorganization of Russian life. As the rest of the world watched the violence unfold, Lenin led the Bolsheviks to victory. Ultimately, Bolshevism would threaten to spread throughout the world. In response to the rise of communist, socialist, and Popular Front governments and organizations, the Society of Jesus, led by Superior General Włodzimierz Ledóchowski (in office, 1915-42), aimed to combat the atheistic ideology. To Ledóchowski, there was no greater danger to Christian civilization than the communism. He issued instructions to the Jesuits to fight against communism just as the members of the Society had originally fought against the Reformation.

There would be some interesting twists and turns, however, in the Jesuits' battle against communist ideology. In this special edition, our authors explore the connections between the Jesuits and communism. We will encounter, in Ainur Elmgren's article, not real life Jesuits, but instead, depictions of Jesuits. These depictions, appearing in newspaper articles, in history textbooks, and in

(C) GRIECH-POLELLE, 2018 | DOI 10.1163/22141332-00501001

This is an open access article distributed under the terms of the prevailing CC-BY-NC license at the time of publication. 
popular fiction, all pointed to the danger Finnish society faced if they allowed "Jesuitism" to take over. In Beth Griech-Polelle's article, we encounter a similar theme, although the real presence of some Jesuits in Nazi Germany meant that there were consequences for the Society, particularly when Hitler and other Nazi ideologues targeted the order as treacherous to the German people.

We then move on examine the position taken by Jesuits. At the center, of course, is Superior General Ledóchowski. Philippe Chenaux's article addresses the role played by Ledóchowski in the fight against communism, including his desire to form a specific secretariat to combat the growing threat of an atheistic system. Connected to Chenaux's research, we then move on to Marisa P. Trythall's examination of a Jesuit, the American Edmund Walsh, and his involvement with the Papal Relief Mission to Russia in 1922-23. Walsh was located, so to speak, at the "ground zero" of communism, and his efforts to protect the Roman Catholic Church and Christianity in general were uppermost in his mind during this mission. Back in America, another Jesuit, John LaFarge, would be attempting to formulate a United Front to take on communism in the United States. Charles Gallagher's article on LaFarge's efforts illuminates a long-neglected aspect of LaFarge's career as his efforts to fight communism are often overlooked by historians. Both Walsh's and LaFarge's careers would intersect with one another over the issue of fighting against communism, but ultimately Ledóchowski and the pope would be the ones to decide what approach the Society would take in combating the "lies of Communism and atheism, the great heresy of our times, more dangerous probably than any heresy of the past." What might have astounded men such as LaFarge, Walsh, and Ledóchowski, was that Jesuits were often accused of working in league with communists to disrupt society in order to profit from the ensuing chaos.

In Ainur Elmgren's article, "The Jesuits of Our Time," we enter Finland in 1917, on the brink of a civil war led by Finnish socialists against the established order. Although the Jesuits were practically a non-existent component of Finnish society at this time, invoking imagery of "the Jesuits" was politically useful in stirring average people to imagine that a militant, anachronistic organization was attempting to drag Finnish society back into the Middle Ages. Political leaders hurled the charge of "Jesuitism" at Socialists and Social Democrats to imply that both Jesuits and Socialists had similar aims: to destroy the Finnish nation and to disrupt public order.

Elmgren highlights the development of the lasting "anti-Jesuit" imagery since the time of the Counter-Reformation in Finland. Jesuits, in the Protestant propaganda of the time, were associated with desires for global domination, disguising their true intentions by manipulating people to achieve their 
aims. This "Jesuit conspiracy" to upend Protestant society was a trope invoked repeatedly. In many writings the public could read about the supposed Jesuit motto, "the end justifies the means." Although counter articles were published to prove that the Jesuits did not, in fact, have such a motto, popular opinion ignored reality and tended to accept the notion that Jesuits were sowing social discontent to achieve their own aims.

Through historical plays, novels, articles, and nationalistic history books, Jesuits played the role of arch villains. Jesuits could be seen as agents of autocracy, obedience to authority, and internationalism. Simultaneously, other images emerged in the early 19oos suggesting that socialists in Finland "are the Jesuits of our time." Jesuit imagery could be used to suggest that there was an internal enemy, on Finnish soil, corrupting the nation through fanatical, intolerant methods. Socialists and Jesuits were linked together in an attempt to "prove" they were one and the same: international agents of upheaval both employing the heartless motto, "the end justifies the means."

In Finland, the struggle for national independence was heightened as the chaos of the Russian Revolution continued to flourish. Militias were formed by both sides resulting in a further breakdown of law and order in the streets. In the face of looting, riots, and strikes, the Finnish press hurled the epithet of "Jesuit" at their political opponents. Both sides invoked "Jesuitical" to imply dishonesty. The socialist side used the term to suggest religious oppression and anachronistic behavior while the conservatives and liberals employed the term "Jesuit" to attack each other for questionable policies towards Russia. The conservatives implied it was "Jesuitical" for socialists to promise independence. It appeared that "Jesuit" as a term could be used against any opponent as the ultimate insult and accusation.

In this increasingly overheated environment, the Finnish government declared its independence from Russia on December 6, 1917. However, inside of Finland, the political forces began to align themselves with their armed militias and it appeared that a civil war was brewing. In this highly charged situation, each side once again deployed the accusation of "Jesuitism" to their opponents. By February 1918, the Finnish Civil War was engulfing the nation.

In the aftermath of the Finnish Civil War, with the triumph of the White forces, socialists were still branded as being "Jesuits." The socialist revolutionaries who had begun the Civil War were portrayed as Jesuits of the "one true faith" of the modern era. Even moderate socialists who had opposed the revolutionaries were accused of following their leaders blindly, "like Jesuits." For moderate Whites, who suggested some sort of reconciliation with the moderate socialists, they could find themselves lumped together as the "Jesuits of Helsinki." 
By the 1920s, a new element was creeping into the familiar anti-Jesuit discourse and that was the added language of anti-Semitism. Now the press could point to conspiracies between Jews and Jesuits, suggesting that Bolshevism was organized and controlled by Jews who lied and sought world power, just like the Jesuits supposedly did. Both Jews and Jesuits, now joined together in imagery, were seen as existential threats to the new Finnish nation.

In Beth Griech-Polelle's article, we find a similar theme to that of Elmgren's research: Jesuits and Jews are portrayed as being one and the same entity posing an existential threat, only this time, it is not in Finnish post-Civil War society, but rather in Nazi Germany. Examining the views of various Nazi leaders, Griech-Polelle seeks to show how Adolf Hitler, Alfred Rosenberg, Dietrich Eckart, and others conflated long-standing stereotypes and imagery of Jesuits with stereotypes of Jewish-ness and Bolshevism. In these leaders' minds, Bolshevism was the product of Jewish materialistic thinking and Jesuitism had been inundated with "Jewish qualities." Both Jesuitism and Jewish-ness were seen as working together to pose an existential threat to the continued success of the German people.

Much like Elmgren's research, negative stereotypes about Jesuits were quite popular and familiar in German society. A strong anti-Jesuit tradition predated the Nazi regime, stretching back into the sixteenth century. Many of the myths and stereotypes regarding the Jesuits supposed quest for world domination, their use of deception and manipulation to gain wealth and power, and the maxim "the end justifies the means" emerge at this early time. In particular, one influential work, the Monita Privata Societatis Jesu (Private directives of the Society of Jesus) appeared as an "expose" of the order. Hieronim Zahorowski, an embittered young man, forged the Monita thereby establishing a pamphlet that enemies of the Jesuits could use as "proof" of the conspiratorial and acquisitive nature of the order. Zahorowski's work, despite being proven to be a forgery, took on a life of its own, helping to further the imagery of Jesuits as being cunning, manipulative, scheming, and greedy for world domination.

As if these qualities were not enough to damn the Jesuits in many enemies' eyes, further elements would be added to compound the threat the Society posed to German society. As time progressed, men such as Dietrich Eckart wrote an influential work depicting Jews as historically deceptive, cunning, manipulative, international and working for world domination. Eckart's work also discussed the rise of Christianity, a movement which he argues was corrupted by "Jewish thinking" from its outset particularly by the writings of St. Paul. Nazi newspapers such as Der Stürmer (The attacker) lent support to the proposition that the Catholic Church had been infiltrated by Jews at its 
highest levels and that, therefore, the teachings of the Church were from the minds of Jews.

Alfred Rosenberg, another early Nazi Party member, wrote a history of the Jews in 1920 and, like Eckart, connected Christianity with Jewish corruption. Using the recently published collection of Rosenberg's diary, Griech-Polelle asserts that Rosenberg saw links between Catholicism and Bolshevism, with some entries implying that Jesuits ruled over the Vatican and were in league with Communist forces fighting in Spain and with Jews all over the world. His assertion was that Jesuits ran the Catholic Church from behind the scenes and that they had imbued the Church with "Jewish and Bolshevik traits."

Hitler revealed his thoughts in Mein Kampf by using the same language of the Monita to describe priests as liars, politically ambitious, and cunning. These same words could be used to describe Jews in Hitler's mind and, according to his great leader theory, it was the genius of a leader who could successfully combine all enemies into one. Thus Jews, Jesuits, Catholicism, and Bolshevism were all combined together and were portrayed as a threat to Germany's continued existence. In Hitler's Secret Conversations, Hitler stated, "Bolshevism is Christianity's illegitimate child. Both are inventions of the Jew." His conversations also reveal how ingrained the anti-Jesuit imagery had become in Hitler's mind: he consistently used language reminiscent of the Monita to describe, in general terms, the crafty manipulations of the Jesuit order, conflating Jesuits with "Jewish qualities" and by extension, seeing Catholicism and Bolshevism as stemming from the same root. Linking Jesuits with Jews, and Catholicism with Bolshevism, allowed Hitler to argue that only one enemy existed for the German people to fight.

Philippe Chenaux's article on Ledóchowski allows us to move away from the specter of Jesuits as they had been imagined in writings, to a real, living Jesuit whose leadership of the Society bridges both World War One and part of World War Two. Ledóchowski became the superior general of the Jesuits on February 11, 1915 but even before his election as leader of the order, he had served as a special counselor for Russian affairs at the Vatican. As the Bolshevik Revolution was unfolding in the opening years of Ledóchowski's leadership of the order, the superior general would play a central role in fighting against the spread of communism. Chenaux explores the link between anti-Semitism and anti-communism in his thinking. Much like in Griech-Polelle's article, intellectuals commonly argued that Jews were at the core of an international conspiracy aiming at world control. The Society's general spoke frequently about the threat posed by Jews and communism. He argued that the Russian Bolshevik Revolution stemmed from an international group of Jews seeking to destroy Christian civilization. 
As the Soviet Union initiated campaigns to interfere with religious practices, Ledóchowski established a secretariat of modern atheism in October 1934. The plan was to counter all communist propaganda with Catholic teachings and ideology. The Society of Jesus was to be in charge of all counter-propaganda. The first publication appeared in May 1935 calling for a Catholic international source to fight against militant atheism. In addition, the Secretariat of Modern Atheism put together exhibitions which provided examples of communist propaganda and its attempts to eradicate Christianity.

Ledóchowski's fight against communism would not end there. He suggested to Pope Pius XI in 1936 that the latter organize Catholics all over the world to engage in battle against communism. Using newly accessible documents from the Vatican, Chenaux shows how deeply involved Ledóchowski was in the publication of the Divini redemptoris encyclical. The encyclical, released in March 1937, condemned communism in no uncertain terms. Although Ledóchowski apparently wanted a reference to connections between Jews and communism, this was ultimately left out by the pope. To the superior general, there was no graver threat than communism to Christian civilization.

Overlapping in time with Ledóchowski's tenure as superior general, Marisa Patulli Trythall's article examines the work of Father Edmund Aloysius Walsh in his role as emissary for the Papal Famine Relief Mission to Russia (1922-23). Trythall's work allows the reader to see how the Vatican viewed the Bolshevik Revolution in real time. Here again, we encounter Ledóchowski, writing to the Vatican secretary of state, offering advice for the thirteen missionaries being sent to Russia. Echoing Chenaux's article, Trythall incorporates direct quotes from Ledóchowski's memo where he baldly states that the Russian Revolution was caused by Jews seeking to destroy Christian civilization. Walsh's travel diary also reveals his thinking when he notes the names of the leaders of the Bolshevik government, highlighting their Jewish surnames "to reveal their true nature." In this, Trythall concludes that Walsh was a man of his time.

Walsh's mission, as delineated by Ledóchowski, was to first and foremost distribute aid to the suffering Russian people. Underneath this instruction was also the desire to win the people back to the Roman Catholic Church. This idea, of winning the Russians back to Roman Catholicism, was also repeated by Colonel William N. Haskell, Director of the A.R.A.'s Mission in Russia, a man who had been converted to Catholicism by Edmund Walsh. For Walsh, his foremost attention needed to be on the central question of freedom of worship inside the Soviet Union. Once he had organized the famine relief measures, he turned his focus to address how free Russians were to worship. Trythall uses the trial and conviction of Archbishop Cieplak and his vicar Constantin Budkiewicz as a test case on freedom of worship. 
Walsh delivered a report on the state of the church in Russia in December 1923. In this report, Walsh raised the point that many of the difficulties, including obtaining the release of Cieplak and the other priests, revolved around the question of recognition: the Soviet Authority had repeatedly intimated that many of the difficulties could be addressed if some sort of diplomatic relations were established between the Vatican and Moscow. The cardinals present offered various possible solutions - including that of appointing an apostolic delegate to Moscow, however, by the end of the meeting all those in attendance had rejected all openings towards the communist regime. Despite a hardening of attitudes towards Moscow by the Vatican, Walsh continued his diplomatic work at a number of organizations for the Holy See.

Leaving one American Jesuit, Edmund Walsh, we now turn our attention to another American Jesuit, John LaFarge, Jr. (1880-1963). Charles Gallagher's article offers a fresh perspective on LaFarge's contribution to the fight against global Communism. In the mid-1930s, LaFarge presented a plan which he called the "United Front." This program suggested that American Jesuits build a Roman Catholic United Front against communism. (Gallagher, 4) Unlike Edmund Walsh, as depicted by Trythall's article, LaFarge believed in having American Jesuits fight against communism in America at the local, grassroots level. This was to be a de-centralized action with local Jesuits responding in their own communities, which was vastly different than the centralizing efforts of the diplomatic Walsh in the Soviet Union.

For Gallagher, there was a five year time period in which American Jesuits were divided on how to counter the spread of communism in the United States. LaFarge, one of the Jesuits who read Ledóchowski's letter "On Combating Communism," believed that his formulation of the United Front would prove to be a successful opponent to the growing Popular Front movements across Europe. To LaFarge and his fellow "frontists" they were engaged in a martial struggle against the greatest heresy of the modern world. The plan was to put forward Jesuit propaganda to counter communist propaganda in a combative manner and have Catholics infiltrate and take over organizations such as the Peace movement, labor organizations, etc. Jesuits were trained to follow their commander, Jesus, and they planned to slay the heresy of atheistic communism.

In the summer of 1935, the split among American Jesuit circles was on full display as the Chicago-Missouri Province held its meeting in West Baden, Indiana. The two differing approaches were encapsulated by the two differing plans presented by Father Daniel A. Lord and Father LaFarge. LaFarge's United Front called on American intellectuals (especially those trained in Jesuit colleges) to be on the frontlines of battle against communist propaganda. 
LaFarge wanted the United Front to attack Russia at every opportunity. This particular policy is striking in that it set LaFarge against Edmund Walsh, who saw America's diplomatic recognition of the Soviet Union as a way to reintroduce God to Russian society.

In contrast to LaFarge's decentralized plan to combat communism anywhere and everywhere, Father Daniel Lord put forward a more centralized program at the West Baden gathering. To perhaps the dismay of LaFarge, Lord's plan was accepted by the American Jesuits. LaFarge did not give up on his idea of a United Front even when Ledóchowski received a report from Father Raymond T. Feely. In Feely's report, no mention was made of LaFarge's comprehensive United Front plan. Instead Father Feely put emphasis on what was essentially Lord's plan, calling for the establishment of a new Christian social order. LaFarge's United Front, although not named specifically by Feely, was portrayed as a negative movement - something which LaFarge and his supporters would not have envisioned. By 1938, LaFarge was attending the $34^{\text {th }}$ International Eucharistic Congress. Eugenio Pacelli was the president of the congress and gave the opening remarks. Imagine LaFarge's surprise when Pacelli spoke of Europeans forming a United Christian Front which would fight to defend Christians against godlessness. Perhaps LaFarge felt some sense of vindication.

LaFarge, Walsh and Ledochowski all viewed themselves as Jesuits fighting a heretical movement of their time. They all employed different methods of attack, but they all shared an understanding of the threat communism posed to Christian civilization. What they might not have anticipated was the conflation of Jesuitism with Bolshevism and socialism. In the case of Finland and Nazi Germany, the long-standing tropes of anti-Jesuitism were used to imply Jesuits and socialists and Bolsheviks were all one the same. 